\title{
Comparison of an amino acid mixture and protein hydrolysates in treatment of infants with phenylketonuria
}

\author{
ISABEL SMITH, DOROTHY E. M. FRANCIS, BARBARA E. CLAYTON, and \\ OTTO H. WOLFF \\ From the Institute of Child Health and The Hospital for Sick Children, London
}

\begin{abstract}
Smith, I., Francis, D. E. M., Clayton, B. E., and Wolff, O. H. (1975). Archives of Disease in Childhood, 50, 864. Comparison of an amino-acid mixture and protein hydrolysates in treatment of infants with phenylketonuria. This study compares three feeding regimens for infants with phenylketonuria diagnosed by neonatal screening. Group 1 (five children) received Minafen (Cow \& Gate) until they weighed twice their birthweights; Aminogran (Allen \& Hanbury) was then added to the feeds in increasing amounts and replaced Minafen at between 8 and 10 months of age. Group 2 (five children) received Aminogran from the neonatal period. Group 3 (five children) received Minafen until they weighed twice their birthweights; Cymogran (Allen \& Hanbury) was then added in increasing amounts and replaced Minafen at between 8 and 10 months of age.

In all three groups growth was normal and control of phenylalanine levels satisfactory. During the first few months of life the Aminogran regimen proved more complicated and caused more practical difficulties than the regimens starting with Minafen. Later in the first year, when mixed feeding was introduced, and particularly when the bottle was exchanged for the cup, Aminogran had advantages over Cymogran because of its low calorie content, small bulk, and less unpleasant taste. At this age feeding problems were fewer and easier to manage with Aminogran than with Cymogran. A method of using Aminogran in the management of such problems is described. For these reasons, the regimen fed group 1 , in which Minafen is used initially and then replaced by Aminogran, is preferred to the other two.
\end{abstract}

The low phenylalanine diet used for the treatment of phenylketonuria requires a protein substitute low in phenylalanine. The preparations available are either hydrolysates of natural proteins from which most of the phenylalanine has been removed (Minafen, Cow \& Gate; Cymogran, Allen \& Hanbury; Albumaid XP, Scientific Hospital Supplies; Lofenalac, Bristol Laboratories (UK)) or mixtures of pure $\mathrm{L}$-amino acids excluding phenylalanine (Aminogran, Allen \& Hanbury; PKU Aid, Scientific Hospital Supplies).

A previous study in children over 20 months of age (Bentovim et al., 1970) showed that Aminogran had advantages over Cymogran. The small bulk and more acceptable taste and smell of the amino-

Received 20 February 1975. acid preparation resulted in a more 'normal' eating pattern. This paper describes the use of Aminogran in a group of infants from the time of diagnosis in the neonatal period, and compares their progress with that of a group treated with protein hydrolysates.

\section{Patients and methods}

Fifteen consecutive neonates diagnosed as suffering from phenylketonuria as a result of routine Guthrie screening (12 cases) or because of an older affected sib ( 3 cases) were admitted to hospital to confirm the diagnosis and to start treatment. Initially they were all thought to have classical phenylketonuria (blood phenylalanine level $>30 \mathrm{mg} / 100 \mathrm{ml}$ and phenylpyruvic acid present in urine), but subsequently two were found to have a higher tolerance of natural protein than is usually found in the classical condition. 
The infants were divided into three groups (Table I). The first five (group 1) were initially treated with Minafen which was gradually replaced by Aminogran between 3 and 10 months. The next five (group 2) were treated with Aminogran throughout. The last five (group 3) were initially treated with Minafen which was gradually replaced by Cymogran between 3 and 10 months. Treatment was started between 7 and 29 days of age.

TABLE I

Dietary regimens used for 15 infants (5 in each of 3 groups) with phenylketonuria (for details of diets see Appendix)

\begin{tabular}{c|c}
\hline Group & \multicolumn{1}{c}{$\begin{array}{c}\text { Protein } \\
\text { substitute }\end{array}$} \\
\hline 1 & $\begin{array}{l}\text { Minafen/ } \\
\text { Aminogran } \\
\text { Aminogran } \\
\text { Minafen/ } \\
\text { Cymogran }\end{array}$ \\
\hline
\end{tabular}

Control of blood phenylalanine levels. Phenylalanine was measured by the Guthrie technique (Lemag working party, 1971) using a capillary sample of blood collected on to a Guthrie test paper. Many parents learnt the technique of blood-taking themselves. Over the first year of treatment phenylalanine levels were measured at least fortnightly and the necessary dietary changes were communicated to the mothers within 48 hours of the blood reaching the hospital. The intake of natural protein was adjusted to maintain blood phenylalanine levels between 3 and $8 \mathrm{mg} / 100 \mathrm{ml}$. Phenylalanine levels were plotted against age for each patient and the duration of levels above $10 \mathrm{mg} / 100 \mathrm{ml}$ and below $2 \mathrm{mg} / 100 \mathrm{ml}$ was calculated from the graph. This procedure, which has been described in a previous study (Smith, Lobascher, and Wolff, 1973), provides a useful measure of the quality of chemical control.

Investigations. A series of investigations was carried out on blood samples taken before the start of treatment and at intervals over the first year. It was not possible to obtain blood after a long fast; instead it was taken just before a feed. A capillary sample of blood was obtained fortnightly from infants in groups 1 and 2 and amino-acid levels were measured by Technicon Aminoacid Analyser. Since our aim was to document plasma amino acids in infants on Aminogran plasma amino-acid levels were not measured in group 3. At 6 weeks and 3, 5, 6, and 12 months after the start of treatment venous blood was obtained for the following investigations: sodium, potassium, urea, bicarbonate, chloride, total proteins and albumin, calcium, magnesium, alkaline phosphatase, haemoglobin, blood film, white cell count, platelet count, and prothrombin time. An $x$-ray picture was taken of the wrist of patients in groups 1 and 2 at 1 year of age.
Follow-up. The dietitian and paediatrician saw the patients initially at fortnightly and afterwards at monthly intervals. Height, weight, and head circumference were measured at each visit and records kept of illnesses, developmental progress, food intake, dietary difficulties, and emotional problems. One patient (group 2) died at 7.5 months of acute myeloblastic leukaemia after an illness lasting one week. A retrospective review of the blood film made one month before death suggested that a few atypical cells were then present in the peripheral blood and the results of investigations done after 6 months of age are excluded from the following study.

\section{Growth.}

\section{Results}

The growth in length and weight of the 15 patients during the first year are shown in the Fig. Birthweights ranged between the 90th and 10th centile except for one patient in group 1, whose birthweight after a 34-week twin pregnancy'was below the 3 rd centile (the 50 th centile allowing for gesta-

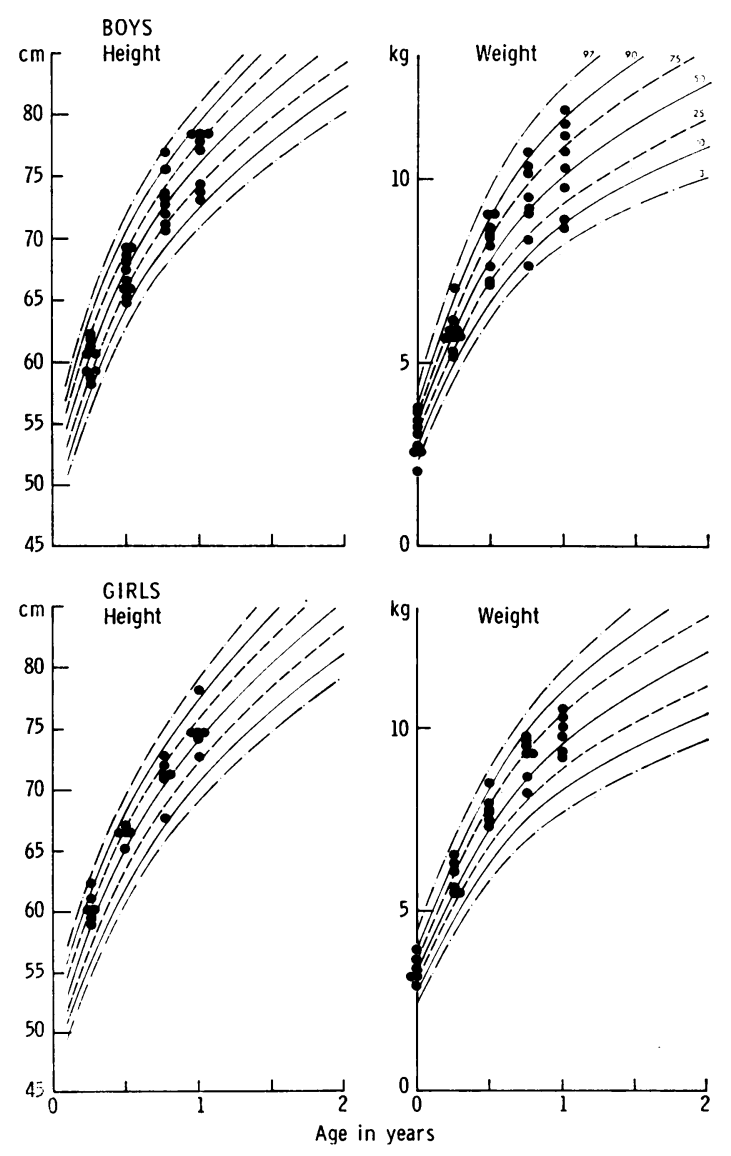

FIG.-Combined growth records of 15 patients. 
tional age). Growth was satisfactory in the three groups. At one year 9 out of the 14 cases had a length and weight on or above the 50th centile, and weight centiles corresponded closely to height centiles. The premature infant (group 1) with a birthweight on the 3rd centile reached the 90th centile for height and weight by 6 months of age (one month ahead of his nonidentical normal twin). At 1 year the mean gains in weight (group 1, $6.7 \pm 0.4 \mathrm{~kg}$; group $26.5 \pm 0.5 \mathrm{~kg}$; group 3 , $6 \cdot 5 \pm 0.7 \mathrm{~kg}$ ) and in height (group $1,16 \cdot 1 \pm 2 \cdot 0$ $\mathrm{cm}$; group 2, 17.0 $\pm 3 \cdot 1 \mathrm{~cm}$; group $3,16 \cdot 0 \pm 4 \cdot 1$ $\mathrm{cm})$ showed no statistical differences between the groups. Head circumference measurements were similarly distributed around the 50th centile and between the 90th and 10th centiles.

\section{Control of blood phenylalanine levels.}

Phenylalanine levels below $2 \mathrm{mg} / 100 \mathrm{ml}$ were rare except in one patient (described later) in whom food intake was erratic. Phenylalanine levels above $10 \mathrm{mg} / 100 \mathrm{ml}$ were more frequent, usually in association with febrile illnesses or feeding difficulties. Comparisons of the grouped means of the duration of phenylalanine levels over $10 \mathrm{mg} / 100 \mathrm{ml}$ (see 'Patients and methods') for the first year of dietary treatment $(0 \cdot 21 \pm 0 \cdot 1$ years for group $1 ; 0.31 \pm 0.17$ years for group 2 ; and $0 \cdot 24 \pm 0 \cdot 14$ years for group 3 ) using a Student's ' $t$ ' test showed no significant difference between the groups.

Investigations. In all patients the results of the following investigations were normal compared with standards in routine use: haemoglobin, red cell appearances, white blood count, platelet count, prothrombin time, sodium, potassium, urea, chloride, bicarbonate, total proteins, albumin, and wrist $x$-ray examination.

Results differing from normal were obtained for the following: calcium, magnesium, alkaline phosphatase, and plasma amino acids. It must be noted, however, that specimens were not obtained after a long fast whereas the normal data used for comparison for calcium, magnesium, and amino acids were derived from specimens obtained in the fasting state.

Amino acids. Certain amino acids could not be accurately quantified. Taurine was not retained on the sample cartridge. Tryptophan and hydroxyproline appeared as low peaks but could not be estimated precisely. Cystine, asparagine, and glutamine began to disappear if there was delay in handling the specimen. Asparagine and glutamine are converted to aspartic and glutamic acids, which may therefore show corresponding increases. Table II shows the grouped means for the amino acid levels obtained between 3 and 12 months of age in group 2 (Aminogran throughout) and compares them with those of a group of normal children on a free diet. 15 out of 18 amino acid mean values were significantly greater in the Aminogran

\section{TABLE II}

Amino acid levels $(\mathrm{mg} / 100 \mathrm{ml}$ ) in infants aged between 3 months and 1 year. Comparison of patients with phenylketonuria (5 patients) on a low phenylalanine diet containing Aminogran with normal infants on a free diet (23 patients). The differences in amino acid levels between the two groups are statistically significant (Student's $t$-test $)(P<0.001)$ except for asparagine and citrulline $(P<0.05)$

\begin{tabular}{|c|c|c|}
\hline Amino acid & $\begin{array}{l}\text { Normal infants } \\
\text { (fasting state) }\end{array}$ & $\begin{array}{c}\text { Infants on aminogran } \\
\left(3 \frac{1}{2}-4 \text { h after }\right. \\
\text { previous feed })\end{array}$ \\
\hline & Mean \pm SD & Mean \pm SD \\
\hline $\begin{array}{l}\text { Aspartic acid } \\
\text { tAsparagine } \\
\text { Threonine } \\
\text { Serine } \\
\text { Glutamic acid } \\
\text { Glutamine } \\
\text { Alanine } \\
\text { Glycine } \\
\text { †Citrulline } \\
\text { Valine } \\
\text { Cystine } \\
\text { Methionine } \\
\text { Isoleucine } \\
\text { Leucine } \\
\text { Tyrosine } \\
\text { †Ornithine } \\
\text { Lysine } \\
\text { Histidine } \\
\text { Arginine } \\
\text { Proline }\end{array}$ & 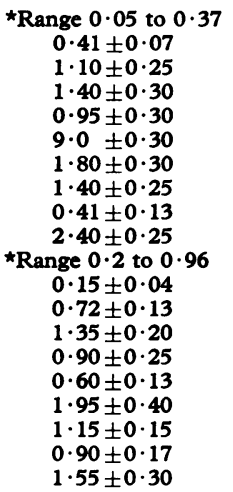 & $\begin{array}{l}0 \cdot 37 \pm 0 \cdot 24 \\
0 \cdot 34 \pm 0 \cdot 05 \\
2 \cdot 58 \pm 0 \cdot 26 \\
2 \cdot 06 \pm 0 \cdot 22 \\
3 \cdot 56 \pm 0 \cdot 42 \\
7 \cdot 3 \pm 0 \cdot 45 \\
3 \cdot 63 \pm 0 \cdot 17 \\
3 \cdot 76 \pm 0 \cdot 51 \\
0 \cdot 27 \pm 0 \cdot 1 \\
3 \cdot 73 \pm 0 \cdot 33 \\
0 \cdot 45 \pm 0 \cdot 1 \\
0 \cdot 75 \pm 0 \cdot 17 \\
1 \cdot 69 \pm 0 \cdot 22 \\
3 \cdot 23 \pm 0 \cdot 39 \\
1 \cdot 55 \pm 0 \cdot 17 \\
1 \cdot 36 \pm 0 \cdot 22 \\
2 \cdot 83 \pm 0 \cdot 28 \\
1 \cdot 53 \pm 0 \cdot 2 \\
1 \cdot 29 \pm 0 \cdot 28 \\
3 \cdot 11 \pm 0 \cdot 36\end{array}$ \\
\hline
\end{tabular}

*Reliable mean values and SDs not available.

tNot present in Aminogran.

group. The values for asparagine and glutamine were significantly lower, which could be accounted for by loss from the specimen, and citrulline was also reduced.

There was no significant difference in amino acid levels between the patients of group 2 (Aminogran) and group I (Minafen/Aminogran), mean values being almost identical for the two groups throughout the first year of treatment.

Calcium. Plasma calcium levels (mean 10.0 $\mathrm{mg} / 100 \mathrm{ml}$, range $9.6-10.6 \mathrm{mg} / 100 \mathrm{ml}$ ) before the start of diet were within or just above the normal 
range $(8 \cdot 5-10 \cdot 5 \mathrm{mg} / 100 \mathrm{ml})$ except for one patient, whose level of $7.8 \mathrm{mg} / 100 \mathrm{ml}$ on the eighth day rose spontaneously to normal over the next 2 weeks. Once dietary treatment had been started levels in all three groups tended to be at the upper limit of normal or above it, ranging from 9.4 to $11 \cdot 1 \mathrm{mg} / 100 \mathrm{ml}$ (mean for group $1,10 \cdot 2 \mathrm{mg} / 100 \mathrm{ml}$; for group $2,10.3 \mathrm{mg} / 100 \mathrm{ml}$; for group $3,10.6$ $\mathrm{mg} / 100 \mathrm{ml}$ ). Over one-quarter of all results (irrespective of the group) exceeded the upper limit of the normal range $(10.5 \mathrm{mg} / 100 \mathrm{ml})$ and only four results fell below the normal mean of $9.7 \mathrm{mg} / 100 \mathrm{ml}$. Fasting specimens obtained in patients with a level above $10.6 \mathrm{mg}$ showed persistently raised levels in 5 patients (two in group 1, one in group 2 , and two in group 3 ).

Magnesium. Plasma levels before the start of the diet were within the normal range $(1 \cdot 7-2 \cdot 2$ $\mathrm{mg} / 100 \mathrm{ml}$ ). On the three dietary regimens they tended to be at the upper limit of the normal range or above it $(1.9-2.5 \mathrm{mg} / 100 \mathrm{ml}$ ) (mean for group $1,2 \cdot 1 \mathrm{mg} / 100 \mathrm{ml}$; for group $2,2.3 \mathrm{mg} / 100 \mathrm{ml}$; for group $3,2 \cdot 2 \mathrm{mg} / 100 \mathrm{ml}$ ). In the absence of a control group of normal infants the statistical significance of the departure from normal of calcium and magnesium levels could not be tested. Patients on Aminogran had the highest mean calcium and magnesium levels in the first three months of treatment and patients on Cymogran had the highest calcium levels at 1 year of age, but these differences between groups do not reach the $5 \%$ level of statistical significance (Mann-Witney test of ranked samples).

Alkaline phosphatase. Before the start of the diet and subsequently values in all three groups tended to be just within or above the upper limit of the normal range ( 10 to $35 \mathrm{~K}-\mathrm{A}$ units) with a mean of $31.5 \mathrm{~K}-\mathrm{A}$ units. The patients with the highest pretreatment values (44, 47, $45 \mathrm{~K}-\mathrm{A}$ units) still showed the highest values at one year $(39,52,39$ $\mathrm{K}-\mathrm{A}$ units), and the patients with the lowest $(18,22)$ still had the lowest values at one year (18 and $23 \mathrm{~K}$-A units). Plasma 5-nucleotidease was measured in patients with raised alkaline phosphatase levels and found to be normal, suggesting that the raised phosphatase level were of bone rather than liver origin.

Clinical progress. In all three groups general clincal progress was satisfactory during the first year. Developmental progress, judged by the acquisition of social and motor skills and the disappearance of primitive reflexes, was normal in all patients, and clinical developmental assessment at 1 year of age was also normal. Minor illnesses such as respiratory and gastrointestinal tract infections were common in all three groups and 2 patients suffered from recurrent wheezing with respiratory illness. One patient had breath-holding attacks from 8 months of age and another, already referred to, died of acute leukaemia at 7 months.

Diet problems. Feeding difficulties occurred in 6 patients during the first year ( 3 in group 1, 1 in group 2, and 2 in group 3). These problems seemed to result from a disturbed mother/infant relationship rather than directly from the diet itself. The 2 patients who developed the most persistent eating difficulties belonged to families where serious emotional distubrance was obvious from the beginning and where 'mothering' was deficient. In one, a boy fostered from 4 months of age, the diet was changed at 14 months from Cymogran to Aminogran without improvement in the eating problems. When he was 21 months old his care was taken over by a new foster mother and the feeding problems promptly disappeared.

The other case illustrates the value of Aminogran in the management of the feeding problems which commonly occur during the treatment of phenylketonuria.

He was the second child of young parents, the mother being of above-average intelligence. There were serious family conflicts and the older, unaffected sib also had feeding problems. After discharge from hospital the mother reported that the baby was restless, particularly at feeding times, and regurgitated Aminogran, milk supplements, and vitamins. She complained bitterly about the diet and it was difficult to obtain clear information about the infant's food intake. Blood phenylalanine levels fluctuated widely and the patient was seen often by the family doctor for minor illnesses. Despite these difficulties the patient gained weight satisfactorily up to 6 months of age, when waight gain slowed down and eczematous patches appeared on face, trunk, limbs, and buttocks. The mother became increasingly agitated and irrationally 'disciplinarian' with her son. At 9 months the patient was taken to the local hospital on two occasions because of minor injuries. When 16 months old he was admitted to hospital because of failure to gain weight, recurrent skin rashes, and alternating hyper- and hypophenylalaninaemia.

The mother refused psychiatric support but benefited from the opportunities for sympathetic discussion of her many problems and from practical help with treatment. Aminogran was given before meals as medicine in a thick paste consisting of about 3-4 teaspoonfuls per meal while the patient was held on the mother's lap, and this was followed by a drink of fruit juice. The mother was encouraged to give praise when the Aminogran had been taken and to avoid punishments. At meal times the patient was offered the foods 
he liked best and allowed to feed himself without urging. Intake was recorded and phenylalanine-containing foods, if unconsumed, were replaced with milk drinks. Generous use was made of high calorie foods such as chips and crisps in measured portions, and low protein bread, pasta, biscuits, fried foods, and sugar. Unconsumed calories were replaced by the addition of Caloreen (Scientific Hospital Supplies) to drinks of milk and squash. With this regimen the rash decreased quickly and weight gain, hair texture, and control of phenylalanine levels improved. The mother, who on admission had been tense and apprehensive, gained in confidence when she learnt to cope with the eating difficulties.

After discharge improvement continued. 3 months later the child was feeding himself Aminogran and many other foods. At 3 years eating remained erratic and control of phenylalanine levels was variable, though growth and general health were satisfactory.

Practical differences in regimens. In infancy the simplicity of Minafen in prescription and preparation, similar to most dried milks (one level, lightly packed scoop to $30 \mathrm{ml}(1 \mathrm{oz})$ of water), was a great advantage. Aminogran contains no fat or carbohydrate and the minerals are separated from the amino acids; bottle feeds are prepared from five measured ingredients (see Appendix) and the calculations are therefore complex.

When between 8 and 12 months of age the patients changed from the bottle to the cup several advantages of Aminogran over Cymogran were noted. Aminogran mixes into a flavoured paste and may be given as 'medicine' (about 3 to 4 teaspoonfuls per meal in the toddler age group). It tastes salty but does not have the penetrating taste and smell of Cymogran. A fruit drink counteracts the high osmolarity of the Aminogran paste and helps to remove its taste and grittiness. 4 of the 5 patients on Cymogran refused the mixture from a cup and bottle-feeding had to be continued until Aminogran was substituted for Cymogran between 14 and 19 months. The management of feeding problems was easier with Aminogran if only because of its smaller volume.

Aminogran supplies only a small part of the total calorie requirements which must therefore be made up with carbohydrate and fat in early infancy and later on with fruit, vegetables, special bread, biscuits, pasta, and other low-protein foods. Such a diet results in a more normal and varied feeding pattern than can be achieved with Cymogran, which has a substantial carbohydrate and fat content so that there is little scope for additional foods.

Another difference between the three dietary regimens concerned bowel function. Aminogran tended to lead to constipation, which was easily corrected by the addition of brown sugar to the feeds. Minafen and Cymogran led to bulky, loose and frequent stools with excoriation of the buttocks in some children and difficulty with toilet training in the toddlers. Loose stools disappeared when Minafen and Cymogran were replaced by Aminogran.

\section{Discussion}

This study shows that treating infants with phenylketonuria with a pure amino-acid preparation (Aminogran) as a protein substitute allows for normal growth and development and satisfactory control of blood phenylalanine levels. With the exception of one patient, who had serious feeding difficulties, no clinical, chemical, or haematological evidence of nutritional deficiency was found with any of the three dietary regimens. During the period of bottle-feeding the prescription and preparation of a diet based on Aminogran is more complicated than that of a diet based on Minafen or Cymogran. Once solid food and the cup replace the bottle Aminogran has advantages because of its small bulk, low calorie content, less unpleasant taste, and lack of smell. Infants receiving Aminogran can be weaned from the bottle earlier and given a more 'normal' toddler diet than is the case with Cymogran. From experience gained in this study we recommend the Minafen/Aminogran regimen as used for group 1. Patients treated with Aminogran are dependent on low-protein foods for most of their calorie requirements, and careful dietetic advice needs to be given to ensure an adequate calorie intake. The management of feeding difficulties was easier with Aminogran than with Minafen or Cymogran.

The high plasma amino-acid levels observed are not unexpected, because it has been shown (Palmer et al., 1973) that 3 to 4 hours after a protein meal plasma amino acids reach a peak level of two to three times the fasting level. In our study blood was obtained at a similar interval after the administration of protein substitute and comparable plasma amino-acid values were obtained. No difference was observed in amino-acid levels between patients on Aminogran and those on Minafen. Thus the presence of D-amino acids in Minafen did not affect the plasma amino-acid pattern. Snyderman et al. (1968) showed that in children receiving amino-acid-based diets fasting plasma amino-acid levels remain normal even with very high intakes (equivalent to $9 \mathrm{~g}$ protein $/ \mathrm{kg}$ ).

There is no obvious explanation for the raised calcium and magnesium levels. Blood specimens were obtained by femoral or jugular puncture by 
one of us (IS), and the high levels are unlikely to be due to venous stasis. Plasma protein levels were normal. The highest calcium levels occurred during the first 3 months of treatment in children on Aminogran and at the end of the first year in those on Cymogran, which coincided with the maximal intake of calcium and magnesium per kilogram of body weight. This was not, however, in excess of that received by artificially-fed infants in the first year of life. A supplement of vitamin D (400 IU/day) was given as Ketovite liquid (Paines and Byrnes). Studies of the mineral balance in patients on synthetic diets (Alexander, Clayton, and Delves, 1974) have shown that infants on Aminogran are in calcium and magnesium balance comparable with that of normal breast-fed babies. Oral tryptophan loading has been reported to lead to hypercalcaemia (Drummond, et al., 1964), an observation which may be relevant since both Aminogran and Cymogran contain supplements of this amino acid. Further studies are needed to elucidate the mechanisms responsible for the high levels of calcium and magnesium, particularly as Bickel (1973) observed renal stones in 3 patients with phenylketonuria.

A rise in plasma alkaline phosphatase unrelated to plasma calcium and magnesium levels was seen in some patients before and during dietary treatment. Similar changes have been reported in other amino-acid disturbances (Levy et al., 1969).

We thank Mr. R. Ersser and Mrs. J. Shepherd for technical assistance; the Joint Research Board of the Institute of Child Health and The Hospital for Sick Children, the Department of Health and Social Security, and Allen \& Hanburys Ltd for financial assistance; and the Medical Research Council for the purchase of an aminoa acid analyser.

\section{RERERENCES}

Alexander, F. W., Clayton, B. E., and Delves, H. T. (1974) Mineral and trace-metal balances in children receiving normal and synthetic diets. Quarterly fournal of Medicine, 43, 89.

Bentovim, A., Clayton, B. E., Francis, D. E. M., Shepherd, J., and Wolff, O. H. (1970). Use of an amino acid mixture in treatment of phenylketonuria. Archives of Disease in Childhood, 45, 640.

Bickel, H. (1973). Treatment of Inborn Errors of Metabolism, p. 77. Ed. by J. W. T. Seakins, R. A. Saunders, and C. Toothill. Churchill, Livingstone, Edinburgh and London.

Clayton, B., Francis, D., and Moncrieff, A. (1965). A method for feeding the phenylketonuric infant. British Medical fournal, $1,54$.

Drummond, K. M., Michael, A. F., Ulstrom, A., and Good, R. (1964). Blue diaper syndrome: familial hypercalcemia with nephrocalcinosis and indicanuria. American fournal of Medicine, 37, 928 .

Lcmag Working Party (1971). Estimation of blood phenylalanine from a dried blood spot using the Guthrie test. Fournal of Clinical Pathology, 24, 576.
Levy, H. L., Shih, V. E., Madigan, P. M., Karolkewicz, V., Carr, J. R. Lum, A., Richards, A. A., Crawford, J. D., and MacCready, R. A. (1969). Hypermethioninemia with other hyperaminoacidemias. American fournal of Diseases of Children, 117, 96.

Palmer, T., Rossiter, M. A., Levin, B., and Oberholzer, V. G. (1973). The effect of protein loads on plasma aminoacid levels. Clinical Science and Molecular Medicine, 45, 827.

Smith, I., Lobascher, M., and Wolff, O. H. (1973). Factors influencing outcome in early treated phenylketonuria. Treatment of Inborn Errors of Metabolism, p. 41. Ed. by J. W. T. Seakins, R. A. Saunders, and C. Toothill. Churchill, Livingstone, Edinburgh and London.

Snyderman, S. E., Holt, L. E., Norton, M., Roitman, E., and Phansalkar, S. I. (1968). The plasma aminogran. I. Influence of the level of protein intake and a comparison of whole protein and amino acid diets. Pediatric Research, 2, 131.

Correspondence to Dr. I. Smith, Institute of Child Health, 30 Guilford Street, London WC1N 1EH.

\section{Appendix}

Aminogran in infants and toddlers. Aminogran is a composite pack of pure L-amino acids (food supplement) and essential minerals including trace elements. An individual scoop measure is provided with each pack ( 1 level scoop of food supplement equals $5 \mathrm{~g}$; 1 level scoop minerals equals $2 \cdot 6 \mathrm{~g}$ ). A method of using the product has already been given for children over 2 years (Bentovim et al., 1970) and the manufacturers publish a comprehensive booklet. The product may be used for infants by adding suitable quantities of carbohydrate and fat or by combining it with Minafen. Both regimens require the addition of measured quantities of natural protein (milk or other food) to supply essential phenylalanine requirements, and the addition of vitamins (Clayton, Francis, and Moncrieff, 1965). Suitable recipes and diet prescriptions are given below (all prescribed according to actual weight), and further details are given by D. E. M. Francis in Diets for Sick Children. (Oxford, Blackwell Scientific Publications, 1975).

\section{Aminogran (as used in group 2)}

Recipe. Aminogran food supplement $2 \mathrm{~g}$, minerals $1 \mathrm{~g}$ (up to a maximum daily total of $8 \mathrm{~g}$ ), carbohydrate (sucrose) $7 \mathrm{~g}$, prosparol $(50 \%$ oil emulsion) $9 \mathrm{ml}$, boiled water to $100 \mathrm{ml}$.

Diet: start of treatment. (1) Cow's milk $30 \mathrm{ml} / \mathrm{kg} /$ day divided between feeds and adjusted according to blood phenylalanine levels (aiming at 3 to $8 \mathrm{mg} / 100 \mathrm{ml}$ ). Infants may require $100 \mathrm{mg}$ phenylalanine/ $\mathrm{kg} /$ day or more during the rapid weight gain of early infancy. (2) Aminogran mixture $150 \mathrm{ml} / \mathrm{kg} /$ day. (3) Ketovite vitamin supplement 3 tablets $+5 \mathrm{ml}$ liquid/day given as medicine. (4) Blackcurrant concentrate $20 \mathrm{ml} /$ day added to feed and calculated as part of carbohydrate content ( $20 \mathrm{ml}$ contains about $12 \mathrm{~g}$ sucrose). (5) Additional fluid from fruit juice or water as necessary. This diet provides per kg body weight/day about $1 \mathrm{~g}$ natural protein $+3 \mathrm{~g}$ amino acids (equivalent to a total of $4 \mathrm{~g}$ protein with $50 \mathrm{mg}$ phenylalanine); 135-140 kcal; $1.5 \mathrm{~g}$ minerals (up to maximum of $8 \mathrm{~g}$ when child weighs $5.5 \mathrm{~kg}$ or over). 
Weaning. Weaning was started according to appetite (not before 8 weeks) with Aminex (Liga) and purees of fruit and low-protein vegetables. At about 6 months potato and grain cereals were added in exchange for part of the milk, and between 6 months and 1 year low-protein biscuits, bread, and pasta were added. With the change from bottle to cup Aminogran food supplement and minerals were mixed as a paste or drink with water and/or flavouring (a drink must be given with this because of its high solute content). Over 1 year the food supplement allowance was reduced to $2 \mathrm{~g} / \mathrm{kg}$, keeping intake constant to allow the patient to grow into the new measure.

\section{Minafen/Aminogran (as used in group 1).}

Recipe. Minafen $20 \mathrm{~g}$, Aminogran food supplement $2 \mathrm{~g}$, minerals $1 \mathrm{~g}$, water to $100 \mathrm{ml}$.

Diet: start of treatment. As for patients in group 2 (above) but with Aminogran omitted and Minafen added. Minafen was given as described previously (Clayton et al., 1965) except that blood phenylalanine levels were controlled at between 3 and $8 \mathrm{mg} / 100 \mathrm{ml}$. When the infant had doubled the birth weight the following regimen was introduced. (1) Milk about $30 \mathrm{ml} / \mathrm{kg} /$ day. (2) Minafen/Aminogran mixture $75 \mathrm{ml} / \mathrm{kg} /$ day. (3) Ketovite tablets and liquid. (4) Blackcurrant concentrate. (5) Weaning. (6) Additional fluid from fruit juice or water as necessary. This diet provides per $\mathrm{kg}$ body weight/day: natural protein $1 \mathrm{~g}$ plus protein hydrolysate $1.87 \mathrm{~g}$; amino acids $1.5 \mathrm{~g}$ (equivalent to about $4 \mathrm{~g}$ total protein with $50 \mathrm{mg}$ phenylalanine); minerals $0.75 \mathrm{~g}$ (from Aminogram and an additonal quantity from Minafen); 100-150 kcal (82 from Minafen/Aminogran mixture and remainder from solids). As the intake of solids increases so the proportion of Minafen in the feed can be gradually decreased and Aminogran increased to supply relatively fewer calories and more total protein from the mixture. This regimen is easily adapatable to the feeding pattern and appetite of the individual child when calculated per $\mathrm{kg}$ body weight/day as follows: total protein $4 \mathrm{~g}$ (from natural protein, hydrolysate, and Aminogran food supplement); $125 \pm 25 \mathrm{kcal}$ (from liquid feeds and solids); minerals none (if Minafen more than $100 \mathrm{~g} /$ day), $2.6 \mathrm{~g}$ (1 scoop) (if Minafen between 50 and $100 \mathrm{~g} /$ day), $5 \cdot 2 \mathrm{~g}$ ( 2 scoops) if Minafen less than $50 \mathrm{~g} /$ day). The change to all Aminogran can be timed to coincide with the change from bottle to cup. 